\title{
Correction to: Investigation of solid oxide fuel cell operation with synthetic biomass gasification product gases as a basis for enhancing its performance
}

\author{
G. Pongratz ${ }^{1}$ (D) V V. Subotić ${ }^{1}$ (D) H. Schroettner ${ }^{2}$ (D) B. Stoeckl ${ }^{1}$ (D) C. Hochenauer $^{1,3}$ (D) $\cdot$ A. Anca-Couce ${ }^{1}$ (D) \\ R. Scharler ${ }^{1,3}$ (iD)
}

Published online: 3 June 2020

(C) Springer-Verlag GmbH Germany, part of Springer Nature 2020

\section{Correction to: Biomass Conv Bioref}

https://doi.org/10.1007/s13399-020-00726-w

The authors want to acknowledge, that during the production of the final version of the publication the image for Figure 9 has been replaced with the image for Figure 12, however without changing the content of the paper. This issue is resolved in the current version of the publication.

The original article has been corrected.

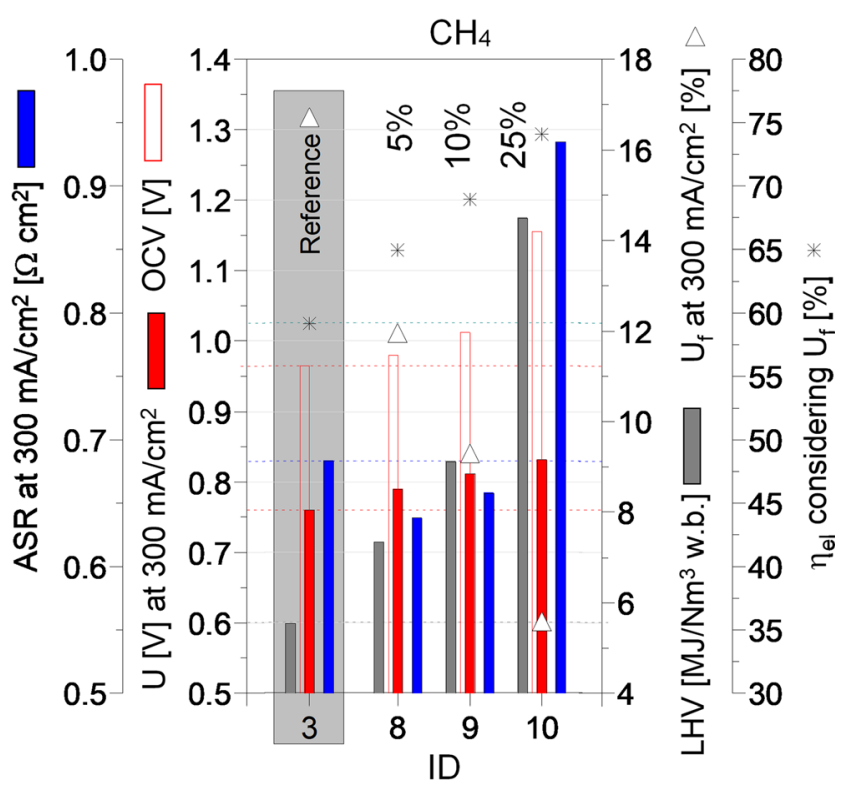

Fig. 9 Comparison of operating points with $\mathrm{CH}_{4}$ with reference mixture

Publisher's note Springer Nature remains neutral with regard to jurisdictional claims in published maps and institutional affiliations.

The online version of the original article can be found at https://doi.org/ 10.1007/s13399-020-00726-w

G. Pongratz

gernot.pongratz@tugraz.at

Institute of Thermal Engineering, Graz University of Technology, Inffeldgasse 21, 8010 Graz, Austria

2 Institute for ElectronMicroscopy and Nanoanalysis, Graz University of Technology, Steyrergasse 17, 8010 Graz, Austria

3 BEST - Bioenergy and Sustainable Technologies GmbH, Inffeldgasse 21b, 8010 Graz, Austria 